\title{
Rules of state budget in Tanzania: control mechanisms and legal challenges to enable state activities.
}

\author{
By Magdalena SYLISTER*
}

\section{A. INTRODUCTION}

This paper has two parts. The first part examines the mechanisms that are in place in the United Republic of Tanzania for controlling state budget. The second part discusses legal challenges associated with those mechanisms in relation to state activities.

There are many definitions of budgetary control but the most relevant one in the context of this paper is from the Financial Dictionary available online. That dictionary defines budgetary control as any process a company or government puts in place to help ensure accuracy and honesty in its budget. ${ }^{1}$ Budgetary control may set goals for expected revenues or planned expenditures. ${ }^{2}$ It almost always includes a system to monitor compliance over time. $^{3}$

\section{B. THE TANZANIAN BUDGET PROCESS}

The budget process is actually about the annual budget cycle events and activities. ${ }^{4}$ Essentially, it involves the determination of resources and their uses for attainment of government objectives. ${ }^{5}$ A sound budget serves as a tool for economic and financial management and accountability and also serves as a mechanism for allocation of resources among different needs and priorities as well as bringing economic stability and growth. ${ }^{6}$

The budget estimates are formulated in line with detailed macroeconomic forecasts on future growth, inflation and external sector (import) trends. ${ }^{7}$ Donor/Government consultations assist the budget process by confirming donor financial commitment to the budget. ${ }^{8}$

* Tanzanian, Assistant Lecturer at the Saint Augustine University of Tanzania, Arusha, Tanzania; LL. M. (Distinction), University of Dar es salaam, Tanzania in association with the University of Bayreuth, Germany; LL. B. (Hons), University of Dar es salaam; Executive Director of the Foundation for Research and Assistance in Law; Advocate of the High Court and courts subordinate thereto save for primary courts, magdalenasylister@gmail.com.

1 https://financial-dictionary.thefreedictionary.com/Budget+Control accessed on 12/09/2020.

2 Ibid.

3 Ibid.

4 https://mof.go.tz/mofdocs/budget/process.htm accessed on 12/09/2020.

5 Ibid.

6 Ibid.

7 Note 4.

8 Ibid. 
These discussions take place between the Ministry of Finance/relevant sectors and Development partners. ${ }^{9}$ After that, the proposed budget goes through a scrutiny and dialogue by various actors and is ultimately tabled before the Parliament for debate and authorisation. ${ }^{10}$ Once the budget is approved, its execution begins. Budget execution is an important stage of the budget process as it is at this stage that actual revenue collections and service delivery takes place. ${ }^{11}$

\section{THE BUDGET CONTROL PROCESS}

\section{Key governing Legal Instruments}

The first one is The Constitution of the United Republic of Tanzania of 1977 (as amended from time to time). Chapter 7 outlines the provisions regarding the finances of the United Republic of Tanzania. The second instrument is the Public Finance Act, 2001 which provides for the legal framework of the budget system with regard to revenue, expenditure control and accountability. The third instrument is the Annual Appropriation Act. This law provides powers to the Minister for Finance to draw money from the Consolidated Fund and allocate it to the various votes. It also provides powers for reallocation of funds between votes. The fourth instrument is the Annual Finance Act which grants powers to the Minister of Finance to raise money by imposing taxes to raise funds to finance the budget. The last instrument is the Budget Act of 2015 which provides for the effective and transparent regulation and oversight of the national budget process.

The budgetary control framework is governed by four fundamental principles namely no tax shall be imposed and no money shall be spent without the authority of the National assembly; expenditure shall be made only for purposes authorized by Parliament; there shall be a single fund known as the Consolidated Fund for receiving and recording all revenues and expenditures, unless otherwise directed by Parliament and the last principle is that all moneys spent from the Consolidated Fund must be accounted for before Parliament. $^{12}$

\section{How Budget Control is Done}

Budget control which also includes monitoring and evaluation are necessary for closer supervision of work programmes and projects. ${ }^{13}$ This involves a continuous monitoring of the plans and budget in order to identify achievements and bottlenecks. ${ }^{14}$ Basically, control

9 Ibid.

10 Ibid.

11 Ibid.

12 https://mof.go.tz/mofdocs/budget/process.htm\#control accessed on 12/09/2020.

13 Ibid.

14 Ibid. 
monitoring and evaluation focuses on ascertaining appropriateness of expenditure and revenue and their conformity to the authorities through financial reports; and management assistance for providing management with information on performance. ${ }^{15}$

Mechanisms for control and monitoring include periodic reporting and follow up, internal audit, external audit, parliamentary control, budget review and adjustments as well as project inspection. ${ }^{16}$ However, the overall control and monitoring of public expenditure is now effected largely through an Integrated Financial management System (IFMS). ${ }^{17}$ This is a computerized system which links up most of the government paying stations. ${ }^{18}$ Therefore most payments are centralized and controlled. ${ }^{19}$ Hardly expenditure or commitment can be incurred without financial provision from IFMS. ${ }^{20}$

In addition to IFMS, Tanzania has established sub-treasuries in all the regions for processing payments from decentralized government Ministries and Regions. ${ }^{21}$ Efforts are underway to establish sub-treasuries in all the Regions. ${ }^{22}$

With regard to involved institutions, as indicated above, various institutions take part in the control process. However, this paper will focus on the role of two most notable institutions namely the Public Accounts Committee (PAC) and the office of the Controller and Audit General (CAG). The focus on those institutions is based on the unique relevance of those institutions to this paper.

The PAC is one of the standing committees of the Parliament of Tanzania. ${ }^{23}$ Among its major functions, the Committee is responsible for scrutinizing government expenditures, government financial year accounts and any other accounts presented to the National Assembly as the Committee deems fit to examine. ${ }^{24}$ It is also mandated to scrutinize the report of the Controller and Auditor General (CAG) ${ }^{25}$ In exercising these functions, it is the duty of the committee to see that moneys reflected in the estimates of expenditure are expended as authorized, and that expenditures are duly authorized by the appropriate authorities under existing accounting procedures. ${ }^{26}$ Committee members are drawn from sitting Members of

15 Ibid.

16 Ibid.

17 Ibid.

18 Ibid.

19 Ibid.

20 Ibid.

21 Ibid.

22 Ibid.

23 RICCARDO PELIZZO AND ABEL KINYONDO, Public Accounts Committees in Eastern Africa: A Comparative Analysis with a Focus on Tanzania, REPOA Brief NO. 44, 2014, available at https://media.africaportal.org/documents/REPOA_BRIEF_44.pdf, p. 1.

24 Ibid.

25 Ibid.

26 Ibid. 
Parliament (MPs) and are appointed by the Speaker. ${ }^{27}$ The PAC is an important body for overseeing the implementation of the budget and the use of public monies. ${ }^{28}$

The PAC has a fairly wide range of powers. ${ }^{29}$ It has the power to examine accounts and financial affairs, the efficiency, economy and effectiveness of government policy, the efficiency and economy of policy implementation (value for money), and the effectiveness of policy implementation (delivery of outcomes) ${ }^{30}$ PAC also enjoys on a conditional basis the power to undertake self-initiated inquiries and to consider the budget estimates. ${ }^{31}$

The PAC is among the committees which have been able to prompt the executive to act on alleged cases of corruption. ${ }^{32}$ A good example is the incident of 2014, when the PAC uncovered a multi-million dollar energy sector graft scandal which involved fraudulent payment of $\$ 120$ million (209 billion shillings) in state funds to a private company. ${ }^{33}$

\section{Legal Challenges}

Despite its efficiency and achievements, the Tanzanian budgetary control mechanism faces a number of critical legal challenges as discussed below;

First, like most other PACs in Sub-Saharan Africa, the Tanzanian PAC faces undue influence from the executive in the execution of its duties. ${ }^{34}$ Parallel to that, the parliament's budgetary oversight function is seen as almost ineffective and a rubber stamping occasion. ${ }^{35}$ Parliament is not seen as playing the important role that it should play in the budget cycle. It does not provide input into the planning phase of the budget as much as it should, it does not demand regular financial reporting from government, and all too often independent audits are late and parliamentary oversight committees do not have adequate resources to scrutinize public accounts. ${ }^{36}$

Although it is agreed that Parliament has clearly defined powers of scrutiny, practice shows that the Legislature is more often than not unable to hold the Executive to account. ${ }^{37}$ This is mainly because Chama Cha Mapinduzi (CCM), the party holding the reins of power in the country, has such a large majority in Parliament that with the exercise of internal par-

27 Ibid.

28 Ibid.

29 ELIJAH DICKENS MUSHEMEZA, The Legislature and Budget Oversight, A Comparative Study of Selected Countries in the East Africa Community, ACODE Policy Research Paper Series No. 71, 2015, available at https://www.acode-u.org/uploadedFiles/PRS71.pdf p. 24.

30 Ibid.

31 Ibid.

32 Ibid., p. 37.

$33 \mathrm{https} / / /$ allafrica.com/stories/201412020469.html accessed on 25/09/2020.

34 MUSHEMEZA, note 29, p. 25.

35 Ibid., p. 37.

36 Ibid.

37 Ibid. 
ty discipline very well established, members have to toe the party line, thus resulting into control by the executive. ${ }^{38}$

The second challenge is about undermining of independence of some actors by the more powerful ones. A good example is the interference, by the Parliament, of the office of the CAG in 2019 which led to the replacement of the former CAG Proessor Mussa Assad. The CAG was removed from office some months after stating that the Tanzanian Parliament is weak due to its failure to take action against some misuse of public funds portrayed in audit reports prepared by the CAG's office. ${ }^{39}$ The CAG made those comments in 2018 during an interview with the United Nations' Kiswahili Service Radio in the United States of America. ${ }^{40}$

Following those comments, in January, 2019, the Speaker of the Tanzanian Parliament ordered Prof Assad/the CAG to appear before the Parliamentary Priviledges Ethics and Powers Committee and respond to allegations of disrespecting the legislative body. ${ }^{41}$ The Speaker emphasized that should Prof Assad fail to honour the summons, then he would be brought before the committee in handcuffs! ${ }^{42}$ A heated debate that tore the nation into two opposition groups occurred. ${ }^{43}$ One group supported the Speaker's move while the other group vehemently opposed it. ${ }^{44}$

Prof Assad complied with the summons and appeared before the Parliamentary Committee for questioning. ${ }^{45}$ After the hearing, the CAG was found guilty of disrespecting the Parliament and the Parliament made a resolution no to continue working with him. ${ }^{46}$ The Speaker went on to suggest that Assad should in fact resign. ${ }^{47}$ The decision to stop working with Prof. Assad came at a sensitive time, just as the Parliament was due to debate the CAG's audit report for the financial year 2017/2018.48

The immediate concern raised by the speaker's critics is that the Speaker is undermining the independence of the CAG, threatening Prof. Assad to discourage proper oversight of public finances. ${ }^{49}$ In November, 2019, Prof. Assad was replaced by a new CAG Mr.

38 Ibid.

39 https://allafrica.com/stories/201901210776.html accessed on 27/08/2020.

40 Ibid.

41 https://www.thecitizen.co.tz/News/1840340-4944246-kf3gz/index.html accessed on 27/08/2020.

42 Ibid.

43 Ibid.

44 Ibid.

45 Ibid.

46 https://www.thecitizen.co.tz/news/CAG-Prof-Assad-warns-of-constitutional-crisis-in-parliament-s/ 1840340-5054202-1k1jsgz/index.html accessed on 27/08/2020.

$47 \mathrm{https}: / /$ presidential-power.net/?p=9503 accessed on 27/08/2020.

48 Ibid.

49 Ibid. 
Charles Edward Kichere. ${ }^{50}$ Interestingly, shortly after his appointment, the new CAG also revealed flaws in government and its institutions as he put in the public domain the annual audit reports which were also tabled in Parliament. ${ }^{51}$ The revealed flaws included, among others, misuse of public resources by making overpayments, payments without contract, payments without actual delivery of services or goods, generally disregarding laid-down public procurement guidelines. ${ }^{52}$

The third challenge is formulation of too ambitious budgets. Budget allocations are not being properly aligned to the available resources ${ }^{53}$ hence some portions of budgets become impossible to implement as desired. For example, in 2018 as of April, the Livestock and Fisheries Ministry had not received a single cent out of the TShs. 4 Billion set aside for development projects under that Ministry. ${ }^{54}$ Professor Delfin Rwegasira ${ }^{55}$ advises that the government should strive to ensure that its budget is realistic and well aligned to the available resources. ${ }^{56} \mathrm{He}$ adds that long-term budget deficits are harmful as they slow down economic growth and indebtedness to foreigners, which is both expensive and risky. ${ }^{57} \mathrm{He}$ recommends that serious parliaments should block or even demand revisions and modifications of ministerial budget proposals if they are found to be economically not making economic sound. ${ }^{58}$

Challenge number four is insufficient budget allocation for some critical sectors such as education, ${ }^{59}$ and health ${ }^{60}$. Insufficient budget for the education sector has been an issue of concern in Tanzania for many years. ${ }^{61}$ The international standard for education sector budget allocation is $20 \%$ of the national budget. ${ }^{62}$ However, the budget for the financial year $2016 / 2017$ constituted $16 \%$ of the national budget, while for the financial year 2017/2018 it was $15 \% .{ }^{63}$ The budget for development expenditure has also not been sufficient, taking into account that funds are usually not disbursed in full. ${ }^{64}$ Insufficient budget allocation makes it difficult for the government to effectively provide services to its people.

50 https://www.thecitizen.co.tz/news/1840340-5335220-9t6axe/index.html accessed on 27/08/2020.

51 https://allafrica.com/stories/202004080217.html accessed on 27/08/2020.

52 Note 51.

53 https://www.thecitizen.co.tz/news/Economists-raise-concerns-over-budget-implementation/184034 0-4599614-x7lh16/index.html accessed on 02/09/2020.

54 Ibid.

55 Of the University of Dar es Salaam's Economics Department.

56 Note 53.

57 Ibid.

58 Ibid.

59 Legal and Human Rights Centre, 2019, p. 113.

60 Ibid., p. 120.

61 Ibid., p. 114.

62 Ibid.

63 Ibid.

64 Ibid. 
Challenge number five is delayed or inadequate disbursement of funds. Delayed disbursement of funds allocated for various sectors such as the health sector is also a key challenge affecting progressive effective realisation of right to health in Tanzania Mainland. ${ }^{65}$ For the financial year 2017/2018, the total of TShs 1,077, 701, 892,000 was set aside for the health sector. ${ }^{66}$ However, by March 2018, the ministry responsible for health had only received $57 \%$ of these funds. ${ }^{67}$

Parallel to that, the government also disburses less of the approved funds in the water sector. ${ }^{68}$ This means that Tanzania will continue to experience water insecurity, and women and other marginalized people, with care taking roles, will continue to suffer disproportionately. ${ }^{69}$ Moreover, the government disburses less of the allocated funds in the agricultural development budget. ${ }^{70}$ It appears that the government only pleases the parliament to get the approval. ${ }^{71}$ This is extremely harmful to the wellbeing of the country. ${ }^{72}$ TGNP advocates for $100 \%$ disbursement of development funds in the agricultural sector. ${ }^{73}$

The sixth challenge is lack of a Parliamentary Budget Office. Tanzania does not have this rather important office. ${ }^{74}$ Parliamentary Budget Offices (PBOs) are designed to prepare economic forecasts that are independent of the executive, analyse budget proposals submitted by the executive, develop budget projections and prepare spending-cut options for legislative consideration. ${ }^{75}$ Establishment of an independent, non-partisan Parliamentary Budget Office would therefore strengthen the legislature's oversight role in the budget process. ${ }^{76}$

In many countries, PBOs are usually independent, non-partisan entities within the legislature that examine the draft annual budget proposed by the executive and provide analytical support to parliamentarians so as to enhance their ability to question the tabled proposal and enable them to propose alternative budget proposals. ${ }^{77}$ Establishment of this institution

65 Note 59, p. 123.

66 Ibid., p. 123.

67 Ibid., p. 123.

68 TGNP MTANDAO, A Comprehensive and Consolidated Budget Digest 2016/17, Budget Review Position Paper, available at https://tgnp.org/wp-content/uploads/2019/04/Budget-Digest-2016_17.p df accessed on 28/08/2020, p. 19.

69 Ibid.

70 Ibid., p. 24.

71 Ibid.

72 Ibid.

73 Ibid.

74 MUSHEMEZA, note 29, p. 38.

75 Ibid.

76 Ibid.

77 Mushemeza, E, D., The Legislature and Budget Oversight, A Comparative Study of Selected Countries in the East Africa Community, ACODE Policy Research Paper Series No. 71, 2015, available at https://www.acode-u.org/uploadedFiles/PRS71.pdf, p. 38. 
in Tanzania would significantly help the MPs in executing their oversight role. ${ }^{78}$ The parliament's budgetary oversight function is therefore deemed hindered due to lack of this office and hence, parliament's oversight role is often regarded largely as a routine scanning and rubber-stamping occasion. ${ }^{79}$

\section{RECOMMENDATIONS AND CONCLUSION}

In order to address those challenges, this paper recommends the following measures to be taken:

The PAC, the Parliament and the CAG's office should be accorded more independence in exercising their budgetary control functions.

The ministries should do away with formulating too ambitious budgets. On the other hand, the Parliament should stop authorising such budgets.

Strategic sectors such as education, agriculture and health should be allocated an adequate amount of funds in the national budget. The minimum amount to be allocated to each of those sectors should be provided for in the law.

Budgeted funds should be disbursed on time and in the required amounts. The law should prescribe disciplinary action against all those responsible for delayed or inadequate disbursement of funds.

Tanzania should establish an independent, non-partisan Parliamentary Budget Office. This paper agrees with Mushemeza that the said office would strengthen the legislature's oversight role in the budget process. ${ }^{80}$

In conclusion, it is undoubted that for many years now Tanzania has been striving to create a strong budgetary control mechanism. However, a number of legal challenges still exist as demonstrated above. Such challenges need to be fully addressed because a properly functioning budgetary control mechanism is very crucial in enabling any democratic government to effectively implement its planned activities and improve the lives of its people.

78 Mushemeza, E, D., The Legislature and Budget Oversight, A Comparative Study of Selected Countries in the East Africa Community, ACODE Policy Research Paper Series No. 71, 2015, available at https://www.acode-u.org/uploadedFiles/PRS71.pdf, p. 38.

79 Mushemeza, E, D., The Legislature and Budget Oversight, A Comparative Study of Selected Countries in the East Africa Community, ACODE Policy Research Paper Series No. 71, 2015, available at https://www.acode-u.org/uploadedFiles/PRS71.pdf, p. 38.

80 Mushemeza, E, D., The Legislature and Budget Oversight, A Comparative Study of Selected Countries in the East Africa Community, ACODE Policy Research Paper Series No. 71, 2015, available at https://www.acode-u.org/uploadedFiles/PRS71.pdf, p. 38. 
Rules of state budget in Tanzania: control mechanisms and legal challenges to enable state activities.

\section{BIBLIOGRAPHY}

https://allafrica.com/stories/201412020469.html accessed on 25/09/2020 https://allafrica.com/stories/201901210776.html accessed on 27/08/2020 https://allafrica.com/stories/202004080217.html accessed on 27/08/2020 https://financial-dictionary.thefreedictionary.com/Budget+Control accessed on 12/09/2020. https://mof.go.tz/mofdocs/budget/process.htm accessed on 12/09/2020. https://mof.go.tz/mofdocs/budget/process.htm\#control accessed on 12/09/2020. https://presidential-power.net/?p=9503 accessed on 27/08/2020 https://www.thecitizen.co.tz/News/1840340-4944246-kf3gz/index.html accessed on 27/08/2020 https://www.thecitizen.co.tz/news/CAG-Prof-Assad-warns-of-constitutional-crisis-in-parliament-s/184

0340-5054202-1k1jsgz/index.html accessed on 27/08/2020 https://www.thecitizen.co.tz/news/1840340-5335220-9t6axe/index.html accessed on 27/08/2020 https://www.thecitizen.co.tz/news/Economists-raise-concerns-over-budget-implementation/1840340-4 599614-x7lh16/index.html accessed on 02/09/2020

https://www.thecitizen.co.tz/news/Economists-raise-concerns-over-budget-implementation/1840340-4 599614-x7lh16/index.html accessed on 02/09/2020

\section{Legal and Human Rights Centre, 2019}

ELIJAH DICKENS MUSHEMEZA, The Legislature and Budget Oversight, A Comparative Study of Selected Countries in the East Africa Community, ACODE Policy Research Paper Series No. 71, 2015, available at https://www.acode-u.org/uploadedFiles/PRS71.pdf

RICCARDO PELIZZO AND ABEL KINYONDO, Public Accounts Committees in Eastern Africa: A Comparative Analysis with a Focus on Tanzania, REPOA Brief NO. 44, 2014, available at https:// media.africaportal.org/documents/REPOA_BRIEF_44.pdf

TGNP MTANDAO, A Comprehensive and Consolidated Budget Digest 2016/17, Budget Review Position Paper, available at https://tgnp.org/wp-content/uploads/2019/04/Budget-Digest-2016_17.pdf accessed on $28 / 08 / 2020$ 